\title{
SURVEI DAN PEMETAAN ZONA KEBISINGAN ARUS LALU LINTAS PADA KAWASAN RSUP DR HASAN SADIKIN BANDUNG
}

\author{
Anni Nurul Aini, Isyria Fadilah Anwar, Angga Marditama Sultan Sufanir, \\ Yackob Astor
}

Jurusan Teknik Sipil, Politeknik Negeri Bandung

E-mail:angga.mss@polban.ac.id

\begin{abstract}
ABSTRAK
RSUP dr.Hasan Sadikin Bandung merupakan rumah sakit rujukan nasional yang mengampu tujuh rumah sakit regional di Jawa Barat dan beberapa rumah sakit di luar Provinsi Jawa Barat. Lokasi rumah sakit yang berada di dekat jalan raya mengakibatkan kondisi kawasan rumah sakit dipengaruhi oleh kebisingan arus lalu lintas, padahal baku mutu yang diijinkan adalah sebesar 55 dBA sesuai dengan kriteria bising menurut KEP48/MENLH/11/1996. Tujuan dari penelitian ini yaitu untuk mengetahui nilai kebisingan secara non-empirik dengan menggunakan alat Sound Level Meter. Pengumpulan data kebisingan dilakukan selama 8 hari pada waktu pagi, siang, dan sore hari dengan cara survei lapangan menggunakan alat Sound Level Meter Model SL-4010. Terdapat 29 titik survei yang terdiri dari 24 titik di luar pagar dan 5 titik di dalam pagar rumah sakit. Hasil survei menunjukkan tingkat kebisingan berkisar antara 61-82 dBA dengan pola sebaran kebisingan disajikan dalam peta zona kebisingan, maka dapat disimpulkan bahwa tingkat kebisingan pada kawasan RSUP dr. Hasan Sadikin Bandung sudah melebihi baku mutu yang diijinkan.
\end{abstract}

Kata Kunci: Kebisingan arus lalu lintas, sound level meter, peta zona kebisingan

\section{PENDAHULUAN}

Kota Bandung merupakan ibu kota Provinsi Jawa Barat, sekaligus menjadi kota terbesar di wilayah Pulau Jawa bagian selatan. Saat ini Kota Bandung menjadi kota tujuan utama pariwisata dan pendidikan, dimana hal tersebut mengakibatkan bertambahnya jumlah kendaraan bermotor yang beroperasi dan berdampak pada peningkatan kebisingan lalu lintas. Dalam tingkat dan waktu tertentu, kebisingan lalu lintas dapat menimbulkan gangguan kesehatan manusia dan kenyamanan lingkungan [1].

Penelitian ini bertujuan untuk mengumpulkan data tingkat kebisingan arus lalu lintas pada kawasan RSUP dr. Hasan Sadikin Bandung dengan cara survei lapangan menggunakan alat Sound Level Meter dan membuat peta zona kebisingan menggunakan Software Surfer. Dari hasil survei dapat diketahui apakah tingkat kebisingan saat ini masih sesuai denganKEP-48/MENLH/11/1996 tentang baku mutu untuk kawasan rumah sakit yaitu sebesar 55 dBA.kebisingan dapat diketahui

\section{KEBISINGAN AKIBAT ARUS LALU LINTAS}

Tingkat kebisingan lalu lintas dipengaruhi oleh volume lalu lintas, kecepatan rata-rata, dan persentase kendaraan berat [2]. Untuk mengukur kebisingan digunakan alat Sound Level Meter yang pengukurannya dikategorikan dalam tiga jenis karakter respon frekuensi, yaitu ditunjukkan dalam skala A, B, dan C. Skala A yang ditemukan paling dapat mewakili batas pendengaran manusia dan respon telinga manusia terhadap kebisingan, termasuk kebisingan yang dapat menimbulkan gangguan pendengaran. Skala A tersebut dinyatakan dalam satuan $\mathrm{dBA}$ [3].

Sound Level Meter umumnya adalah alat genggam dengan mikrofon.Diafragma mikrofon pada alat ini merespon perubahan tekanan udara yang disebabkan oleh gelombang suara, dan menampilkan tingkat tekanan suara (dB) [4]. Berikut gambar Sound Level Meter dapat dilihat pada Gambar 1 


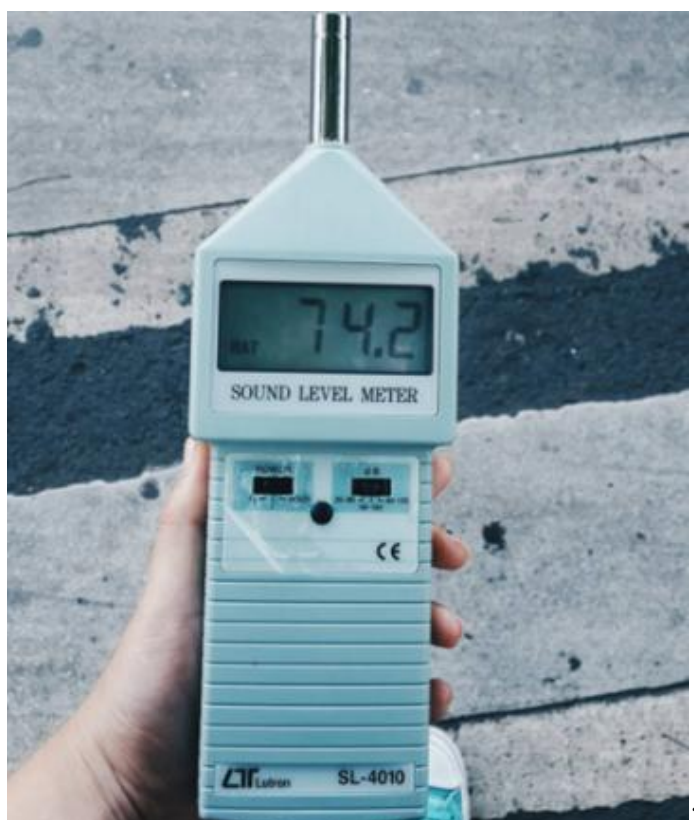

Gambar 1. Sound Level Meter Model SL-4010

Tingkat kebisingan yang dapat diterima oleh manusia dari segi kesehatan tergantung pada berapa lama pendengaran terpapar kebisingan. Tingkat kebisingan yang masih bisa ditolerir oleh manusia tergantung pada kegiatan apa yang sedang dilakukan. Seseorang yang sedang sakit, beribadah dan belajar akan merasa terganggu dengan kebisingan yang sangat kecil sekalipun [3].

Penanganan kebisingan berdasarkan Pd.T-16-2005B tentang Prediksi Kebisingan Akibat Lalu Lintas dibagi menjadi tiga yaitu: (1) Penanganan kebisingan pada sumber, dengan cara: pengaturan lalu lintas, pembatasan kendaraan berat, pengaturan kecepatan, perbaikan kelandaian jalan, pemilihan jenis perkerasan jalan. (2) Penanganan kebisingan pada jalur perambatan, dengan cara pemasangan Bangunan Peredam Bising (BPB). Peredam bising dapat berupa penghalang alami (natural barrier) dan penghalang buatan (artificial barrier).Penghalang alami biasanya menggunakan berbagai kombinasi tanaman dengan gundukan (berm) tanah, sedangkan penghalang buatan dapat dibuat dari berbagai bahan, seperti tembok, kaca, kayu, aluminium, dan bahan lainnya. (3) Penanganan kebisingan pada titik penerimaan, dengan cara: penggantian jendela dengan kaca jendela ganda, pemasangan dinding peredam, pemasangan sistem ventilasi khusus.

\section{SOFTWARE SURFER}

Surfer adalah salah satu perangkat lunak yang digunakan untuk pembuatan peta kontur dan pemodelan 3 dimensi (3D) dengan mendasarkan pada grid. Perangkat lunak ini melakukan plotting data tabular XYZ tak beraturan menjadi lembar titik-titik segi empat (grid) yang beraturan [5].
Gridding merupakan proses pembentukan rangkaian nilai $\mathrm{Z}$ yang teratur dari sebuah data XYZ. Hasil dari proses gridding ini adalah file grid yang tersimpan pada file.grd. Namun pada penelitian ini Software Surfer digunakan untuk membuat pemetaan kebisingan, maka nilai $\mathrm{Z}$ tersebut bukan lagi berupa titik ketinggian atau kedalaman.

\section{METODOLOGI PENELITIAN}

Pengumpulan data dilakukan dengan cara survei kebisingan sesuai dengan Pd.T-10-2004-B menggunakan alat Sound Level Meter Model SL4010 pada 29 titik survei yang terdiri 5 titik di dalam pagar rumah sakit (Gambar 2a) dan 24 titik di luar pagar (Gambar 2b).

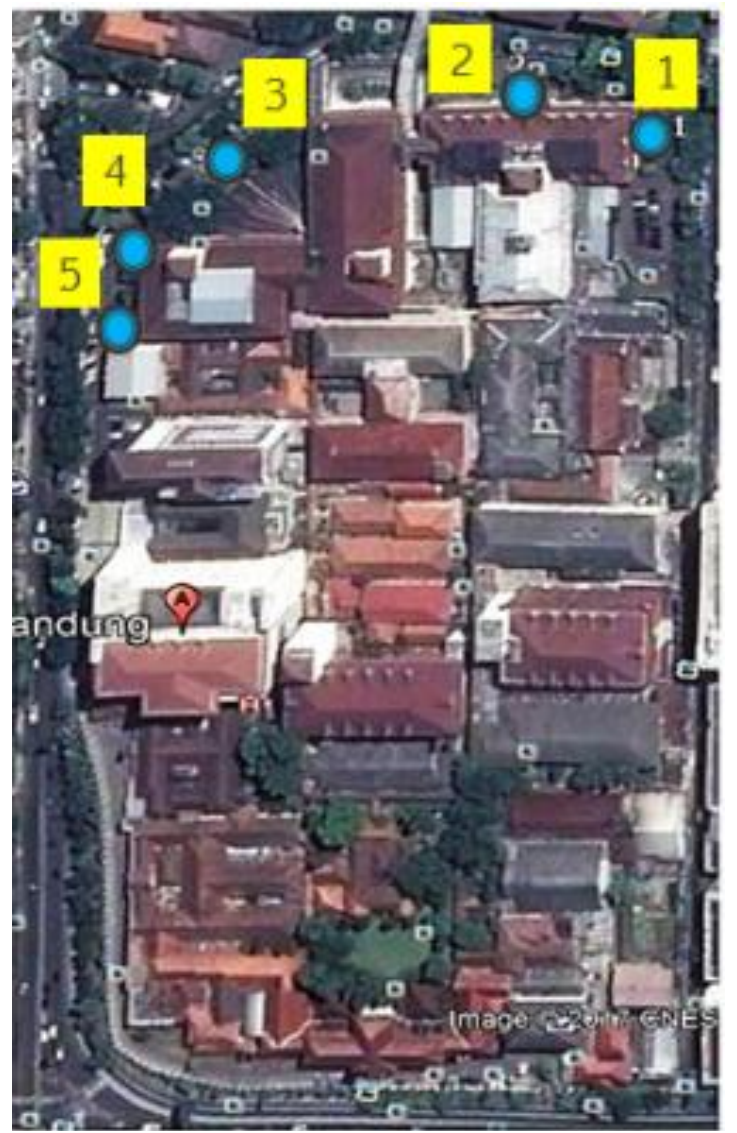

Gambar 2a. Titik-titik Survei Kebisingan di dalam Pagar Rumah Sakit

Pengumpulan data yang dilakukan di dalam pagar rumah sakit bertujuan untuk mendapatkan nilai kebisingan yang hasilnya dapat digunakan untuk mencari nilai perambatan bising. Sebelum survei dilaksanakan, perlu dilakukan penentuan titik survei dan koordinat titik tersebut. Penentuan titik pada tahap ini dikhususkan pada area yang berdekatan dengan ruang rawat inap dan IGD. Setelah itu proses pengambilan data dapat dilaksanakan di setiap titik survei yang telah ditentukan sesuai dengan waktu pengamatan yang telah ditentukan. 


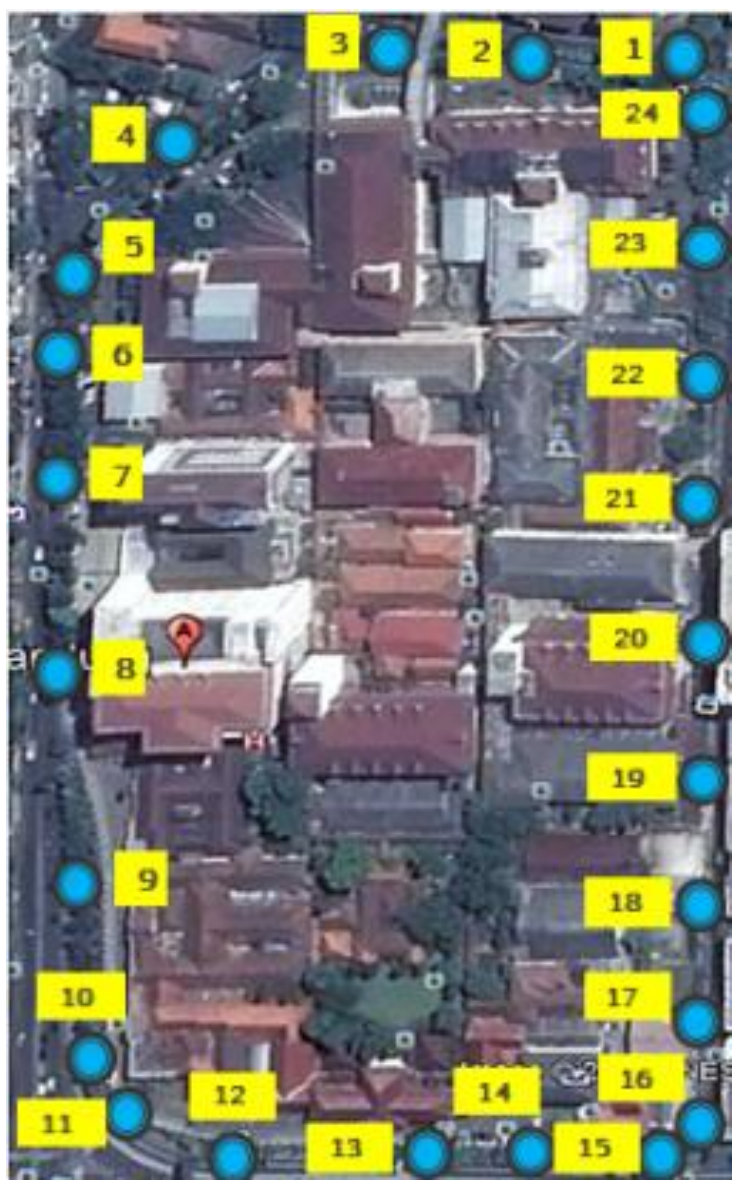

Gambar 2b. Titik-titik Survei Kebisingan di luar Pagar Rumah Sakit

Sedangkan, pengumpulan data yang dilakukan di luar pagar rumah sakit bertujuan untuk mendapatkan nilai kebisingan yang hasilnya akan diplotkan untuk pemetaan zona kebisingan pada Software Surfer. Sebelum survei dilaksanakan, perlu dilakukan penentuan titik survei dan koordinat titik tersebut. Setelah itu proses pengambilan data dapat dilaksanakan di setiap titik survei yang telah ditentukan sesuai dengan waktu pengamatan.

Survei kebisingan dilakukan selama 2 minggu (22 April - 3 Mei 2017), dalam 1 minggu dilakukan survei selama 4 hari yaitu 2 weekday (Selasa dan Rabu) dan 2 weekend (Sabtu dan Minggu). Pengambilan data pada weekday dan weekend dilakukan untuk mengetahui perbedaan kebisingan pada saat weekday dan weekend. Dalam 1 hari dibagi menjadi 3waktu pengamatan yaitu pada pukul 06.30 - 08.00 WIB, 11.30 - 13.00 WIB, dan 16.00 - 17.30 WIB.

Setelah semua data terkumpul, data koordinat XY dan nilai kebisingan disalin ke Notepad, nilai kebisingan digunakan sebagai nilai $\mathrm{Z}$ pada Software Surfer. Penempatan nilai XYZ pada Notepad dapat dilihat pada Gambar 3.

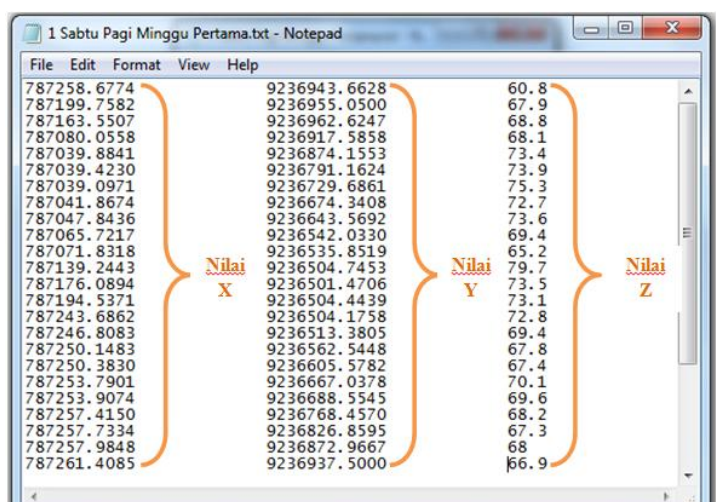

Gambar 3. Nilai XYZ untuk Input pada Software Surfer

Dari data XYZ tersebut dibuat file grid yang selanjutnya dibuat menjadi Peta ZonaKebisingan pada Kawasan RSUP dr. Hasan Sadikin Bandung. Untuk memperjelas hasil sebaran kebisingan, dimasukan gambar tampak RSUP Dr. Hasan Sadikin Bandung yang telah di plot menggunakan Citra Satelit. Peta Zona Kebisingan dibuat sesuai dengan waktu pengamatan yang telah ditentukan sehingga dapat terlihat perbedaan tingkat kebisingannya. Untuk mengecek kesamaan data hasil survei dengan data yang sudah diplot ke dalam Software Surfer, maka perlu menyesuaikan nilai dBS dari data hasil survei dengan nilai dBA yang ada di peta zona kebisingan untuk setiap titik survei.

\section{HASIL DAN PEMBAHASAN}

Pola penyebaran kebisingan per-waktu pengamatan disajikan dalam peta zona kebisingan (Gambar 4), dari peta tersebut dapat diketahui titik-titik yang memerlukan bangunan peredam bising. 


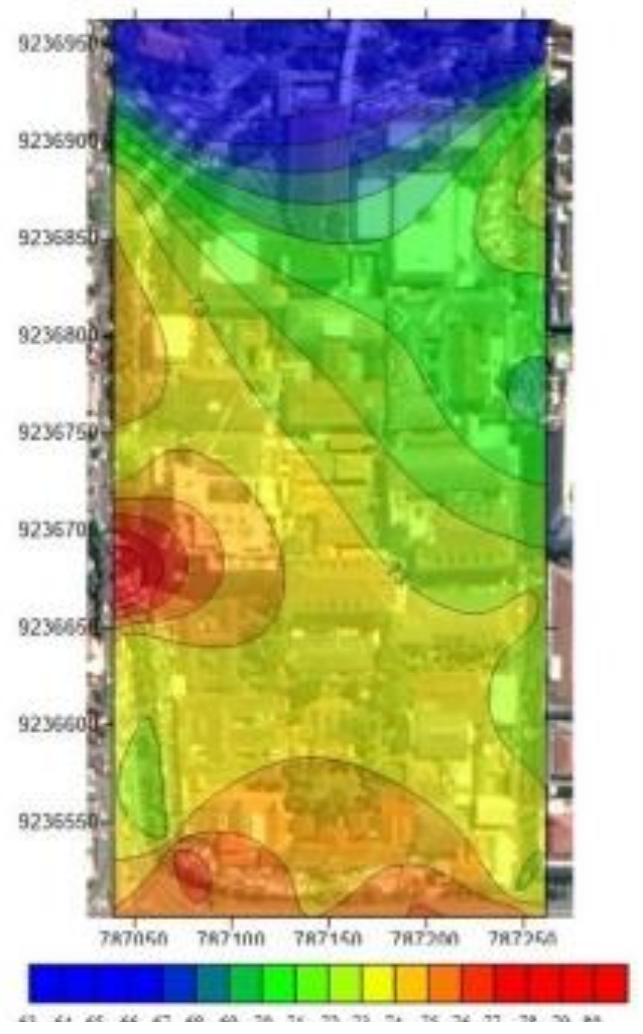

Gambar 4a. Peta Zona Kebisingan Kawasan RSUP dr. Hasan Sadikin Bandung pada Pagi hari

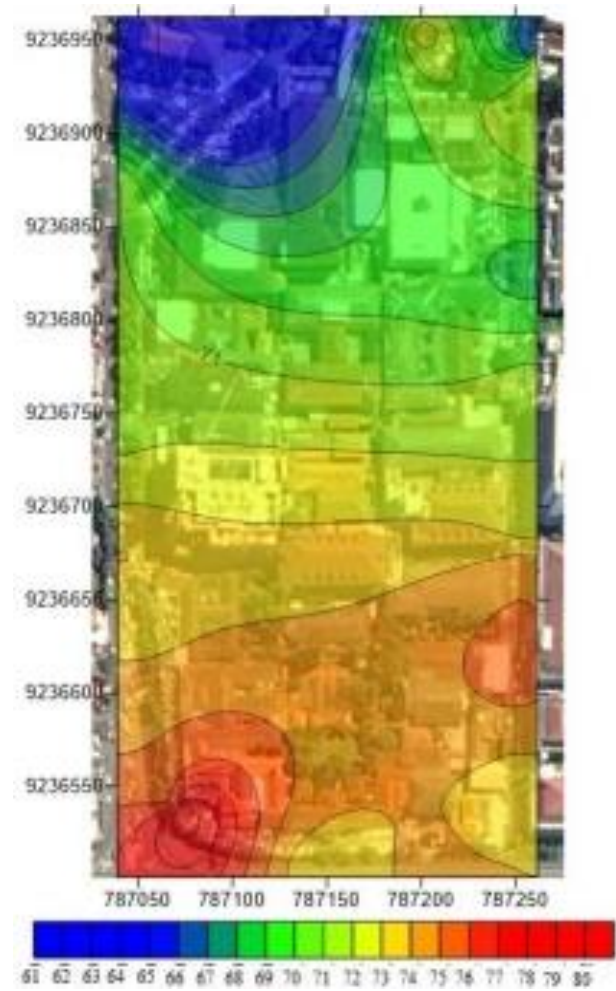

Gambar 4b. Peta Zona Kebisingan Kawasan RSUP dr. Hasan Sadikin Bandung pada Siang hari

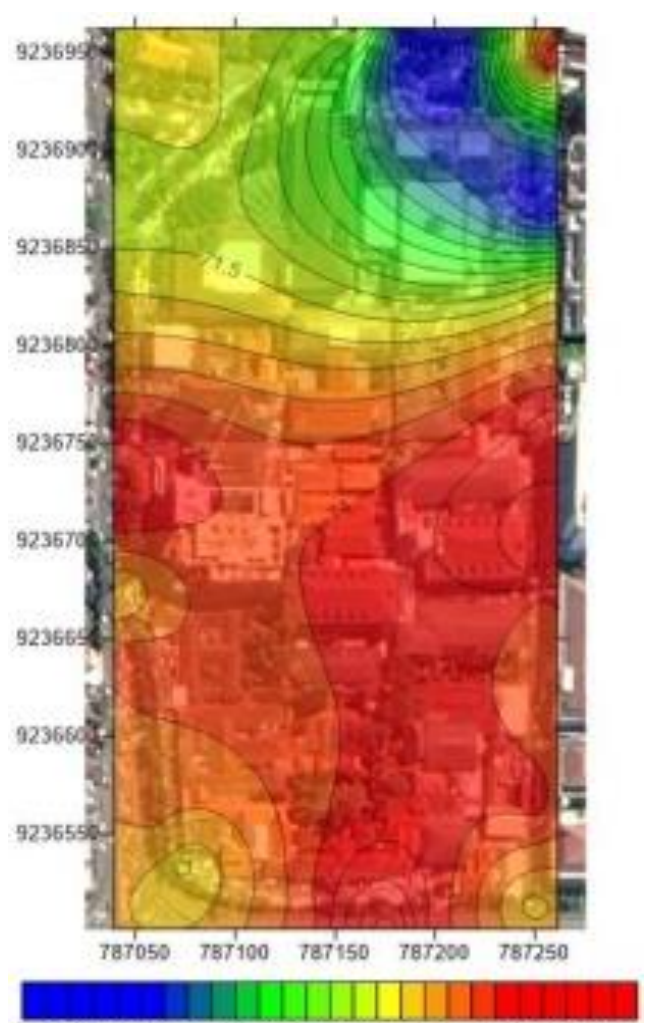

Gambar 4c. Peta Zona Kebisingan Kawasan RSUP dr. Hasan Sadikin Bandung pada Sore hari

Berdasarkan hasil survei didapat nilai tingkat kebisingan berkisar antara $61-82 \mathrm{dBA}$, dengan kata lain sudah melebihi baku mutu yang diijinkan yaitu sebesar 55 dBA. Oleh karena itu diperlukan penanganan untuk mengendalikan masalah kebisingan tersebut,antara lain dengan cara:

Kecepatan rata-ratakendaraan di Jl. H.O.S. Tjokroaminoto, Jl. DR. Djunjunan, dan Jl. Prof. Eyckmanlebih dari $60 \mathrm{~km} / \mathrm{jam}$, padahal jalan-jalan tersebut berdekatan dengan ruang rawat inap dan IGD. Perlu dipasang rambu batas kecepatan untuk mengatur kecepatan lalu lintas dengan rentang 30 $60 \mathrm{~km} / \mathrm{jam}$, cara ini dapat mengurangi tingkat kebisingan 1 - $5 \mathrm{dBA}$.

Menanam pohon atau tanaman yang lebih rimbun di area yang berdekatan dengan ruang rawat inap dan IGD.

Pagar eksisting terbuat dari tiang-tiang besi, sehingga perlu diganti dengan beton pracetak agar tidak ada celah dan mampu meredam bising secara lebih baik, cara ini dapat mengurangi tingkat kebisingan 10 - 15 dBA.

Mengganti jendela rumah sakit dengan kaca jendela ganda, pemasangan dinding peredam, dan pemasangan sistem ventilasi khusus. Efektivitas Penggunaan bahan kaca sebagai jendela untuk penghalang kebisingan biasanya dilakukan dengan tujuan untuk mempertahankan nilai estetika lingkungan dengan mengupayakan tetap terlihatnya pemandangan di seberang jalan dari sisi yang lain dan sebaliknya. 


\section{KESIMPULAN}

Berdasarkan hasil surveikebisingan arus lalu lintas pada Kawasan RSUP dr. Hasan Sadikin Bandung,dapat disimpulkan bahwa:

Tingkat kebisingan pada 29 titik survei sudah melebihi baku mutu yang diijinkan dalam KEP48/MENLH/11/1996 [7].

Peta zona kebisingan hasil dari Software Surfer menunjukan sebaran tingkat kebisingan di sisi utara (Jl. Prof.Eyckman) dan timur (J1. Rumah Sakit) lebih rendah dibandingkan dengan di sisi barat (Jl. H.O.S. Tjokroaminoto) dan selatan (Jl. Dr. Djunjunan).

\section{DAFTAR PUSTAKA}

[1] Griefahn et al. 2000.Physiological, subjective, and behavioural responses during sleep to noise from rail and road traffic, Noise and Health Interdisciplinary International Journal, Fed. Rep. Germany.

[2] Setiawan, A. 2014.Pengaruh Kecepatan dan Jumlah Kendaraan terhadap Kebisingan (Studi Kasus Kawasan Kos Mahasiswa di Jalan Raya Prabumulih-Palembang Km 32 Indralaya Sumatera Selatan, Jurnal Teknik Sipil dan Lingkungan Vol. 2 No. 4, Desember 2014: 609-614.

[3] Djalante. 2010. Analisis Tingkat Kebisingan di Jalan Raya yang Menggunakan Alat Pemberi Isyarat Lalu Lintas (APIL), Jurnal SMARTek, Vol. 8No.4, November 2010: 280-300.

[4] Wikipedia, Sound Level Meter,https://en.wikipedia.org/wiki/Sound_level_m eter (19 Februari 2017)

[5] Wahyudi, A. 2012,Garis Kontur, Sifat dan Interpolasinya,http://www.adip.greenbox.web.id/20 12/11/garis-kontur-sifat-dan-interpolasinya/ (20 Juli 2017)

[6] Buchari. 2007.Kebisingan Indusrti dan Hearing Conservation Program, USU Respository: Universitas Sumatera Utara, Medan.

[7] Menteri Negara Lingkungan Hidup. 1996. Baku Mutu Kebisingan,Surat Keputusan Menteri Lingkungan Hidup Nomor: Kep-48/MENLH/1996/25, November 1996, Jakarta.

[8] Departemen Pemukiman dan Prasarana Wilayah, 2004, Prediksi Kebisingan Akibat Lalu Lintas Pd.T10-2004-B, Jakarta.

[9] Departemen Pekerjaan Umum,2005, Mitigasi Dampak Kebisingan Akibat Lalu Lintas Jalan Pd.T16-2005, Jakarta. 